\title{
DOKUMENTA
}

Dr DRAGOMIR BONDŽIĆ, naučni saradnik

Institut za savremenu istoriju

Beograd, Trg Nikole Pašića 11

\section{DOKUMENTA O DRŽANJU MITRE MITROVIĆ U SLUČAJU MILOVANA ĐILASA 1954. GODINE*}

Milovan Đilas (12. jun 1911 - 20. april 1995) rođen je u Podbišću kod Mojkovca u Crnoj Gori. Završio je gimnaziju u Beranama i 1929. upisao se na grupu za jugoslovensku književnost na Filozofskom fakultetu u Beogradu. Tokom studija je objavljivao književne radove i priključio se studentskom revolucionarnom pokretu. Oktobra 1932. postao je član KPJ i sekretar partijske organizacije Beogradskog univerziteta. Uhapšen je 1933. i osuđen na tri godine zatvora. Od 1937. bio je član najvišeg partijskog rukovodstva, CK KPJ i Politbiroa CK KPJ i jedan od najbližih saradnika Josipa Broza Tita. Uzeo je učešće u pokretanju ustanka 1941. Tokom rata je bio član Vrhovnog štaba NPV i POJ i učestvovao je u svim važnijim vojnim, političkim, propagandnim i diplomatskim aktivnostima. Učestvovao je u radu i formulisanju odluka Drugog zasedanja AVNOJ-a u Jajcu 29. i 30. novembra 1943. U Privremenoj vladi DFJ koja je formirana 7. marta 1945. bio je ministar za Crnu Goru i ministar bez portfelja. Posle rata se kao član vlade, jedan od sekretara CK KPJ i rukovodilac Agitprop odeljenja CK KPJ bavio pretežno pitanjima prosvete, kulture, ideologije i propagande. Istovremeno, učestvovao je u nekoliko diplomatskih misija i predvodio jugoslovensku delegaciju na zasedanjima Generalne skupštine OUN. Januara 1953. izabran je za jednog od potpredsednika SIV-a, a decembra iste godine i za predsednika Savezne narodne skupštine. ${ }^{1}$

Đilas je kao jedan od najviših funkcionera KPJ i najjačih partijskih ideologa i teoretičara predvodio radikalnu kritiku staljinističkog dogmatizma i sovjetskog modela socijalizma posle sukoba Jugoslavije sa Sovjetskim Savezom 1948. On se zatim početkom 50-ih isticao u traženju novog

${ }^{*}$ Rad je deo projekta Srpsko društvo u jugoslovenskoj državi u 20. veku - između demokratije i diktature (177016) koji finansira Ministarstvo prosvete, nauke i tehnološkog razvoja Republike Srbije.

1 Јелена Попов, Милован Билас, Српски биографски речник, том 3, Нови Сад 2007, 496-499; Kosta Nikolić, Srđan Cvetković, Rađanje jeretika. Suđenje Milovanu Đilasu i Vladimiru Dedijeru 1955. godine, Beograd 2011, 24-33. 
jugoslovenskog puta u socijalizam i insistiranju na samoupravljanju, liberalizaciji, demokratizaciji partije i društva, diskusiji i slobodi mišljenja. Njegove ideje su prihvaćene na VI kongresu KPJ novembra 1952, koji je predstavljao vrhunac liberalizacije i demokratizacije partije i države u Jugoslaviji. Đilas se, međutim, mimo stavova ostatka državnog i partijskog vrha zalagao za produbljivanje procesa demokratizacije i liberalizacije i oštro kritikovao partijski monopol, stavljanje Partije iznad zakona i moralnu hipokriziju društvene i političke birokratije. Stavove je izneo u nizu članaka u listu Borba od 11. oktobra 1953. do 7. januara 1954, kao i u časopisu Nova misao, posebno u članku „Anatomija jednog morala“ januara 1954. Partijsko rukovodstvo se ogradilo od Đilasovih ideja i on je na III vanrednom plenumu CK SKJ oštro kritikovan, osuđen zbog revizionizma i izbačen iz CK. Dao je ostavku na položaj predsednika Savezne narodne skupštine i uskoro sam izašao iz Saveza komunista. Bio je izopšten iz javnog života, ali nastavio je da dalje razvija svoje ideje o demokratiji i da kritikuje jugoslovensko partijsko rukovodstvo. Onemogućen u zemlji, svoje stavove je objavljivao u inostranstvu u izjavama štampi i nizu publikacija. Zato je progonjen, više puta osuđivan i odležao višegodišnju robiju. Tek uvođenjem političkog pluralizma u Jugoslaviji početkom 90 -ih godina dozvoljeno mu je učešće $u$ javnom životu. $^{2}$

Pored toga što se posle III plenuma odvijao progon i izolacija samog Đilasa vršeni su i različiti pritisci na sve one koji su podržavali ili se nisu izričito ogradili od njegovih ideja ili su nastavili da se viđaju sa njim. „Đilasovci“" su kritikovani na partijskim sastancima, isključivani iz SKJ, praćeni od strane UDB-e, gubili posao, itd. ${ }^{3}$ Poseban pritisak je vršen na Vladimira Dedijera $^{4}$ i Mitru Mitrović, Đilasovu bivšu suprugu, ${ }^{5}$ koji su se na III plenu-

${ }^{2}$ Đilasovu biografiju i literaturu o njemu videti u: J. Попов, н. g., 496-499; К. Nikolić, S. Cvetković, $n$. d., 24-80.

3 Videti svedočanstva u: Борислав Михајловић Михиз, Ауйобиоі̄paфuја - o gруїима, II, Београд 1993, 139-190; Добрица Ћосић, Пишчеви зайиси (1951-1968), Београд 2000, 36-63, 106-109; Milovan Đilas, Vlast i pobuna, Beograd 1991, 289-297.

${ }^{4}$ Vladimir Dedijer (Beograd, 1914 - Boston, 1990), novinar i istoričar. Završio je Pravni fakultet u Beogradu. Bio je član KPJ od 1939, učesnik NOB od 1941, jedan od rukovodilaca Agitpropa. Posle rata je obavljao niz partijskih i državnih funkcija, bio je član CK SKJ, biograf Josipa Broza i autor više publicističkih i istoriografskih dela. Izabran je za profesora na Filozofskom fakultetu u Beogradu ali zbog podrške Đilasu 1954. nije stupio na dužnost. Posle toga je izbačen iz SKJ, doktorirao na Pravnom fakultetu 1956, držao predavanja u inostranstvu, postao član SANU 1967, itd. - Биљана Шимуновић-Бешлин, Влаguмuр Деguјер, Српски биографски речник, том 3, Нови Сад 2007, 132-134.

${ }^{5}$ Mitra Mitrović (Požega, 1912 - Beograd, 2001), društveno-politička radnica i književnica. Kao student Filozofskog fakulteta stupila je u studentski revolucionarni pokret, postala član SKOJ-a 1931. i KPJ 1933. Završila je studije 1935. i nastavila sa partijskim ilegalnim radom, posebno u Ženskom pokretu. Početkom rata 1941. odvedena u logor na 
mu stavili na Đilasovu stranu i nisu ga osudili. ${ }^{6}$ Njih je pratila policija, prijatelji su prestajali da im se javljaju, bojkotovani su, a na IV plenumu CK SKJ 29-30. marta 1954. doneta je odluka da Kontrolna komisija CK ispita njihovo držanje i istupanje na III plenumu, kao i držanje pre plenuma. ${ }^{7}$ Posle više meseci tokom kojih su nastavljani pritisci, kontrola, praćenje i bojkot, Kontrolna komisija je usmeno i pismeno saslušala Vladimira Dedijera i Mitru Mitrović, ispitala „njihove slučajeve“. Reakcija V. Dedijera na poziv Kontrolne komisije, njegova izjava data londonskom Tajmsu i potom Đilasova izjava Njujork tajmsu, doveli su do produbljivanja „afere Đilas“, žive reakcije inostrane štampe i do prvog suđenja Đilasu (i Dedijeru) januara 1955. i prve, uslovne, osude na 18 meseci zatvora. ${ }^{8}$ Kontrolna komisija je podnela saopštenje na VI plenumu CK SKJ 13-14. marta 1956. na osnovu kojeg je Vladimir Dedijer i formalno razrešen članstva u SKJ. Zaključeno je da je Mitra Mitrović pre i tokom III plenuma podržavala M. Đilasa te je odlučeno da bude udaljena sa dužnosti člana CK SKJ, ali da se protiv nje ne primenjuje neka od Statutom predviđenih kazni pošto je kasnije javno označila svoje stavove kao zablude i iluzije i ogradila se od dalje akcije Đilasa i Dedijera. ${ }^{9}$

Dosije o držanju Mitre Mitrović povodom slučaja Milovana Đilasa 1954. godine nalazi se u Kontrolno-statutarnoj komisiji CK SKJ u Arhivu Jugoslavije. Dosije sadrži pet dokumenata: 1) pismo M. Mitrović Komisiji sa izvinjenjem zbog kašnjenja sa izveštajem; 2) izveštaj Kontrolne komisije o držanju Mitre Mitrović u slučaju Milovana Đilasa; 3) izveštaj o praćenju Mitre Mitrović; 4) pismena izjava Mitre Mitrović Kontrolnoj komisiji; i 5) pismo Mitre Mitrović Borbi u kojem se ograđuje od izjava Milovana Đilasa i Vladimira Dedijera stranoj štampi. ${ }^{10}$ Ovde objavljujemo dosije u celini, bez ikakvih izmena i sa osnovnim komentarima i objašnjenjima, smatrajući ga

Banjici, ali uspela da pobegne i pristupi partizanskom pokretu u kojem je obavljala važne funkcije. Bila je član PK KPJ za Srbiju i Glavnog narodnooslobodilačkog odbora Srbije, član Centralnog odbora AFŽ, i član AVNOJ-a od 1942. Posle rata je bila član Agitpropa CK SK Srbije, ministar prosvete Srbije, predsednik Saveta za prosvetu i kulturu Srbije, republički i savezni narodni poslanik, član CK SKS i CK SKJ. U braku sa Milovanom Đilasom bila je od maja 1936. do marta 1952. Posle III plenuma uklonjena je iz CK SKS i CK SKJ i sa drugih funkcija i nastavila da radi u Saveznom zavodu za školstvo. Bavila se i publicističkim radom. - Ko je ko u Jugoslaviji, Beograd 1957, 469; Зашишишнии, НИН-а, НИН, 19. април 2001, 21.

${ }^{6}$ Videti: Arhiv Jugoslavije (AJ), fond CK SKJ, 507, II-11, III plenum CK SKJ, 1617. januar 1954.

${ }^{7}$ AJ, fond CK SKJ, 507, II-12, IV plenum CK SKJ, 29-30. mart 1954.

${ }^{8}$ Više u: K. Nikolić, S. Cvetković, n. d., 80-312; M. Đilas, n. d., 296-299.

${ }^{9}$ AJ, fond CK SKJ, 507, II-11, VI plenum CK SKJ, 13-14. mart 1956. Videti i:

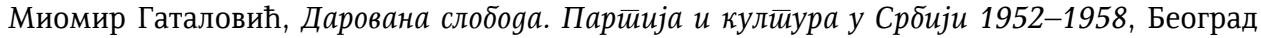
2010, 203.

${ }^{10} \mathrm{AJ}$, fond CK SKJ, 507, Kontrolno-statutarna komisija, VII-k.VIII/4. 
važnim i slikovitim svedočanstvom o mehanizmu obračuna Partije sa članom optuženim za „pogrešan politički stav i držanje“ povodom važnog unutarpartijskog sukoba, kao i o ličnim dimenzijama tog sukoba.

\section{1)}

Druže Krsto, ${ }^{11}$

Tri dana posle razgovora sa vama devojčica ${ }^{12}$ mi se teško razbolela i još uvek je u krevetu. Uz to sam nedelju dana, za vreme prvih dana njene bolesti, radila u Zakonodavnom odboru Srbije, a zatim nekoliko dana i pre i posle podne u Odboru za prosvetu Savezne skupštine. I sama se zdravstveno osećam vrlo rđavo, pa se nadam da ćeš shvatiti što ranije nisam napisala ovaj izveštaj, računajući i s tim što ste mi rekli da ne moram žuriti.

22. decembar 1954.

Drugarski pozdrav

Mitra Mitrović ${ }^{13}$

2)

\section{CENTRALNI KOMITET SAVEZA KOMUNISTA JUGOSLAVIJE}

Izveštaj kontrolne komisije o držanju drugarice Mitre Mitrović u slučaju Milovana Đilasa ${ }^{14}$

CK je na svom Četvrtom plenarnom sastanku zaključio da se poveri Kontrolnoj komisiji da ispita, pored držanja Vladimira Dedijera, i držanje Mitre Mitrović, kao člana CK, pre Trećeg plenuma i na Trećem plenumu i da Centralnom komitetu podnese izveštaj sa predlogom kako da se njeno pitanje reši. $^{15}$

Kontrolna komisija je ispitala držanje drugarice Mitre Mitrović i podnosi Centralnom komitetu sledeći izveštaj:

1. Drugarica Mitra Mitrović je pre Trećeg plenuma zastupala ista gledišta kao i Đilas po pitanju razvoja Saveza komunista, demokratije, i dr.

${ }^{11}$ Krsto Popivoda (1910-1988) pravnik, član KPJ od 1933, učesnik NOB-a, narodni heroj, član AVNOJ-a i CK KPJ. Posle rata narodni poslanik, ministar i član SIV-a. Član Kontrolne komisije CK SKJ. - Narodni heroji Jugoslavije, Beograd 1975.

${ }^{12}$ Reč je o Vukici Mitrović (1948-2001), ćerki Mitre Mitrović i Milovana Đilasa.

${ }^{13}$ Tekst dokumenta je kucan ćirilicom.

${ }^{14} \mathrm{U}$ tekstu je običnom olovkom dodavano slovo j i tako ekavica pretvarana u ijekavicu.

${ }^{15}$ Vidi: AJ, fond CK SKJ, 507, II-12, IV plenum CK SKJ, 29-30. mart 1954. 
To je potvrdila ona sama u svom govoru na Trećem plenumu, u usmenoj i pismenoj izjavi datoj Kontrolnoj komisiji.

2. Ona je ova gledišta zastupala i posle poznatog saopštenja Izvršnog komiteta CK u kome su osuđeni stavovi i akcije Đilasa i kojim je zakazan Treći plenum CK koji je Đilasov slučaj raspravio. ${ }^{16}$

3. Na Trećem plenumu Mitra Mitrović je i dalje, iako konfuzno, zastupala ista gledišta zato što se - kako sama kaže u izjavi datoj Kontrolnoj komisiji - slagala sa izvesnim stavovima u njegovim člancima i što je želela da utiče na ublažavanje ocene koja će se doneti o Đilasu.

4. Objašnjavajući svoje istupe na Trećem plenumu u izjavama datim Kontrolnoj komisiji ona je isticala da je na njen odnos prema Đilasu u to vreme izvanredno uticalo to što je sa njim provela dugogodišnji zajednički život. Na Trećem plenumu, pak, svoj govor je počela uveravanjem CK da ni iz kakvih subjektivnih razloga faktički ne bi mogla da brani ličnost Đilasa i da zbog toga ne govori u vezi sa njim lično. Kontrolna komisija nije mogla drukčije da objasni ovu kontradikciju nego njenim pokušajem da kod članova CK stvori utisak da diskutuje sa principijelnih pozicija i da u razvoju stvari pre Trećeg plenuma nema nikakvog udela. Svrha toga vidi se jasno iz njenog govora na Plenumu koji predstavlja prividan pokušaj da se diskusija skrene sa Đilasovog slučaja na neka nebitna pitanja kako bi na taj način bila stvorena situacija na Plenumu u kojoj bi Đilasov slučaj mogao biti ocenjen kao dopustivo razmimoilaženje u gledištima, a ne onako kako je taj slučaj Treći plenum CK ocenio. ${ }^{17}$

5. U izjavama datim Kontrolnoj komisiji Mitra Mitrović je kategorično tvrdila da se nije sa Đilasom i Dedijerom dogovarala o istupanju na Plenumu, mada su, kako je izjavila, u danima neposredno pred Treći plenum Đilas i Dedijer kod nje dolazili i sa njom vodili razgovore o nastaloj situaciji.

6. Na Trećem plenumu CK glasala je za odluku CK o slučaju Đilas. ${ }^{18}$

7. U svojoj izjavi datoj štampi 29. decembra 1954. god. drugarica Mitra Mitrović se javno ogradila od poznate antijugoslovenske akcije koju

${ }^{16}$ Saopštenje u kojem se ističe da su članci Milovana Đilasa plod njegovog sopstvenog mišljenja, suprotnog mišljenju ostalih članova Izvršnog komiteta, odlukama VI kongresa i II plenuma, i kaže se da će to pitanje biti izneto na sledećoj sednici. - Borba, br. 7, 10. januar 1954, 1.

${ }^{17}$ AJ, CK SKJ, 507, II-11, III plenum CK SKJ, 16-17. januar 1954; Borba, br. 15, 19. januar 1954, 2.

${ }^{18} \mathrm{U}$ odluci plenuma se kaže da su Đilasovi stavovi suprotni liniji VI kongresa SKJ, da su uneli zabunu u javnost i učinili štetu SK i interesima zemlje, da se Đilas udaljio od CK i SK i stvorio osnovu za razbijanje jedinstva SK i da se zato isključuje iz CK SKJ, udaljuje sa svih funkcija u SK i kažnjava poslednjom opomenom. - AJ, CK SKJ, 507, II-11, III plenum CK SKJ, 16-17. januar 1954; Borba, br. 14, 18. januar 1954, 1. 
su Đilas i Dedijer pokrenuli preko nekih listova u inostranstvu. U istoj izjavi ona se indirektno ogradila i od sopstvenih shvatanja koja je imala u vreme Trećeg plenuma CK, koja je shvatanja označila kao svoje iluzije, zablude. (vidi dokument 5 )

Iz svega ovoga Kontrolna komisija je mogla da zaključi:

da je Mitra Mitrović ne samo delila shvatanja Milovana Đilasa koja je Treći plenum odbacio i osudio, nego bila spremna i da pomogne realizovanju takvih shvatanja,

da je pre Trećeg plenuma i na Trećem plenumu CK podržavala ta shvatanja i pored očiglednosti štete koju su shvatanja i akcija Milovana Đilasa pričinila i mogla pričiniti zemlji i Savezu komunista.

Zbog ovoga je Mitra Mitrović kao član CK SKJ izgubila poverenje članova Saveza komunista, čije su skoro sve osnovne organizacije posle Trećeg plenuma CK tražile razjašnjenje njenog držanja na Trećem plenumu, a što je naročito došlo do izražaja u činjenici da na Kongresu Saveza komunista Srbije nije izabrana za člana CK Srbije, iako je do tada bila član toga CK. ${ }^{19}$

Na osnovu svega ovoga Kontrolna komisija predlaže:

da se drugarica Mitra Mitrović udalji sa dužnosti člana CK Saveza komunista Jugoslavije pošto je imala za člana CK SKJ nedopustivo pogrešan politički stav i držanje u slučaju Milovana Đilasa.

da se protiv nje ne primenjuje neka od Statutom predviđenih kazni pošto je docnije javno označila svoje držanje oko Đilasovog slučaja kao svoje zablude, iluzije, i ogradila se od dalje akcije Đilasa i Dedijera.

Kontrolna komisija čini ovakav predlog i na osnovu stečenog utiska da će drugarica Mitra Mitrović kao član Saveza komunista koristiti ukazanu pomoć da do kraja sagleda ne samo svoje iluzije i zablude, nego svu štetnost Đilasove delatnosti u Savezu komunista Jugoslavije.

3)

\section{Mitra Mitrović $^{20}$}

Već pre dve godine međusobno su se zbližili kao jedna grupa književnici i umjetnici: Oskar Davičo, Dobrica Ćosić - Gedža, Borisav Mihajlović - Mihiz, Antonije Isaković, Žika Stojković i Mića Popović. ${ }^{21}$ Do zbliženja

${ }^{19}$ III kongres SKS je održan 26-29. aprila 1954.

${ }^{20}$ Tekst je nepotpisan i sadrži podatke i pretpostavke dobijene praćenjem Mitre Mitrović i Milovana Đilasa i ljudi koji su bili sa njima u kontaktu. Delovi teksta su podvučeni grafitnom olovkom.

${ }^{21}$ Oskar Davičo (1909-1989) književnik, nadrealista, pre rata član KPJ, učesnik NOB; Dobrica Ćosić (1921) književnik, član KPJ, učesnik NOB, posle rata narodni poslanik i 
ovih došlo je uglavnom što se međusobno smatraju najtalentovanijim i što su manje više istih pogleda na književnost, slobodu kritike i značaj njihove uloge, kao takve, u književnom stvaranju. Da bi imali više mogućnosti za rad i da bi postigli što veći uspeh i doživeli što bolju afirmaciju, oni su preko Dobrice Ćosića, koji je bio veliki prijatelj sa Mitrom Mitrović, uspeli da se čvrsto povežu sa Mitrom Mitrović i Đilasom i da preko njih ostvare pun uticaj u prosvjetnim ustanovama i izdavačkim preduzećima u Beogradu. Kroz svakidašnji kontakt ovih sa Mitrom i Đilasom došlo je do punog ličnog prijateljstva između svih gore navedenih s jedne strane i Mitre i Đilasa s druge strane. Tako je Dobrica Ćosić, imajući veliki uticaj kod Mitre, omogućavao preko nje pojedincima od ovih da dobijaju razne stipendije za rad i usavršavanje $u$ inostranstvu, kao i dotacije pri izdavanju svojih književnih dela. Tako je na primer Ćosićev roman „Daleko je sunce“ dotiran u sva tri izdanja, Davičova „Pesma“ isto tako u oba dosadašnja izdanja, iako se inače praktikovalo da se dotiraju pojedina dela samo u prvom izdanju. Stipendije za boravak u inostranstvu na više meseci dobili su Mihiz, Mića Popović i drugi koji su njima bili bliski po koncepcijama. Osim toga Đilasov i Mitrin sud za dela navedenih književnika bio je uvek pohvalan, što ih je još uvek popularisalo. ${ }^{22}$

Do slučaja sa Đilasom vrlo često su se okupljali kod Mihiza i Miće Popovića na Sajmištu. ${ }^{23}$ Kod njih su već tada vrlo često dolazili i Mitra i Đilas, pa su zajednički pretresali događaje, donosili sud o pojedinim literarnim delima, pa su tek nakon tih i takvih diskusija u javnosti istupali, uvek jedinstveno.

U toku Đilasovog slučaja, i od njega na ovamo, međusobni kontakti ovih književnika sa Mitrom i Đilasom postali su sve češći i čvršći. Mitra vrlo često odlazi na stan kod Mihiza i Žike Stojkovića i sa njima diskutuje o toku Plenuma, njenom stavu na Plenumu i o odnosu pojedinih rukovodioca prema njoj od Plenuma na ovamo.

Mitrina veza sa Mihizom je naročito simptomatična. Svi elementi ukazuju na to da je Mitra pod neverovatnim ličnim uticajem Mihiza. U svim diskusijama i razgovorima oni su vrlo intimni i Mitra nesumnjivo prema njemu ima podređen stav. Više puta njoj Mihiz na perfidan način stavi do

član Agitpropa CK SKS, od 1968. opozicionar i kritičar SKJ, član SANU (Gedža je nadimak iz rata); Borislav Mihajlović Mihiz (1922-1997) književni kritičar, esejista, dramski pisac; Antonije Isaković (1923-2002) književnik, član SANU; Živorad Žika Stojković (1922-1998) urednik u izdavačkim kućama, sekretar Srpske književne zadruge, lektor srpskog jezika u Bordou; Miodrag Mića Popović (1923-1996) slikar, likovni kritičar, pisac, režiser, član SANU.

22 O odnosima Mitre Mitrović i Milovana Đilasa sa navedenim književnicima i umetnicima videti: Б. Михајловић Михиз, н. g., 29, 30, 69, 139-189; Д. Ћосић, н. g., 36-63; M. Đilas, n. d., 289-296.

${ }^{23}$ Na Starom sajmištu. Videti: Б. Михајловић Михиз, н. g., 23-27. 
znanja kao da ne drži mnogo do nje, što ovu veoma ražalosti i odmah mu prebacuje da je prema njoj neopravdano grub, da ona to ne zaslužuje i sl. Mihiz je zadnjih meseci nekoliko puta bio kod nje na stanu i to najčešće na njen zahtev, navodno radi dogovora u vezi literature. U vezi sa ovim potrebno je napomenuti da su u književnom svetu već pre Đilasovog slučaja kružile priče da je Mitra u intimnim odnosima sa Mihizom i Dobricom Ćosićem.

Prema pričanju doktorke Marije Gajić, njoj je Mitra nekoliko dana posle III plenuma pričala sa ogorčenjem o utiscima sa Plenuma. U jednom takvom razgovoru ispričala je o istupu u prilog Đilasa, objašnjavajući joj to na sledeći način: „Kada sam ušla u salu i videla da je Đido sam, nasuprot svim ostalim koji su se spremali da ga raznesu, bilo mi je užasno teško. Osetila sam da moram govoriti, ali nisam znala kako. Pomislila sam da će me dete posle nekoliko godina pitati gde sam ja tada bila. I možda je bolje što sam odmah govorila, jer tada još nisam znala kako je stvar pripremljena i kakvi će strašni događaji biti. Da sam to sve prethodno čula, svakako ne bi mogla ni reč progovoriti." Kada joj je Gajićka rekla da je Plenumom, posle Đilasa, najviše izgubio Tito jer je sada ostao na milost i nemilost Slovencima, Mitra je odgovorila: „I pored svega Tito se na Plenumu najbolje držao. Ali ipak ovo Tito nije smeo učiniti, jer je strašno i nečovečno postupiti tako prema čoveku koji mu je 20 godina bio najbolji prijatelj i saradnik".

U toku daljeg razgovora Mitra je vrlo oštro napala druga Mošu Pijade, govoreći da se on držao bezobzirno, da je on napao Đilasa zbog honorara a sam zarađuje velike pare. ${ }^{24}$ Zatim kaže, kako posle njenog istupanja na Plenumu niko od prisutnih nije smeo da joj priđe. Na kraju je rekla: „Sada sam ostala sama, bez prijatelja, a izložena napadima sa sviju strana. Prosto postoji utakmica u lošim postupcima prema meni“.

Gajićka je takođe pričala kako joj se Mitra u više navrata žalila da je nesrećna i nesređena i kako je zbog svih okolnosti i maltretiranja koja je doživljavala, tražila od rukovodstva da je oslobodi nekih zaduženja da bi se povukla na rad samo u Beogradu, jer da više ne može izdržati.

Žika Stojković priča da je, kada je negde u maju kod njega bio Đilas sa ženom, zatim Mihiz i Mića Popović, bilo vrlo veselo i zanimljivo, pa da je sutradan vidio Mitru i pričao joj o tome dodavši da bi i nju bio zvao ali da to

${ }^{24}$ Moša Pijade (1890-1957) revolucionar, slikar, novinar, član KPJ od 1920, učesnik NOB-a, potpredsednik i jedan od autora odluka AVNOJ-a. Posle rata bio član Politbiroa CK KPJ, narodni poslanik, potpredsednik SIV-a i predsednik Savezne narodne skupštine. Član SANU. - Narodni heroji Jugoslavije, Beograd 1975. Njegovo istupanje na III plenumu videti u: AJ, CK SKJ, 507, II-11, III plenum CK SKJ, 16-17. januar 1954; Borba, br. 15, 19. januar 1954, 5 . 
nije učinio zbog Đilasove žene Štefice. ${ }^{25}$ Kaže da mu je Mitra na to rekla da to nikada i ne pokušava, već ako mu što treba neka on dođe do nje. Ovo zbog toga da se kod Žike ne bi srela sa Đilasom. Tada mu je navodno rekla da je Đilas njeno veliko razočarenje ispričavši mu tom prilikom sledeći detalj: „Kada sam ostala u drugom stanju između nas je već postojalo razmimoilaženje. Đilas mi je tada prebacio da sam u drugom stanju ostala samo zato da bi ga vezala za sebe. Tada sam se odmah odlučila za razvod. Kada se dete rodilo, Milovan uopšte nije hteo da ga vidi pa sam nekoliko meseci morala da ga skrivam, da ga držim u nekoj sobi na mansardi, a posle da ga dam svojoj majci na čuvanje. Kada sam pre godinu dana bila bolesna, spremala sam se da odem kod druga Tita i da mu kažem da mi je jedina želja ako umrem da dete ne izdržava Milovan Đilas". U nastavku ovog razgovora dodala je: „Ja sam imala dve ljubavi: Milovana Đilasa i Revoluciju. Milovan je ubio oba-dve!"

Međutim iako je tako govorila, Mitra se preko leta a naročito u zadnje vreme vrlo često sastajala sa Đilasom. Obično Đilas odlazi kod nje na stan i uvek nastoje da budu sami tj. kad nema niko kod Mitre u stanu. Đilas obično kod nje dolazi noću. Zapaženo je da se sastaju i u parku i da su naročito oprezni da ne budu zapaženi zajedno.

Osim toga, ona se preko Žike Stojkovića i ostalih koji su u svakodnevnom kontaktu sa Đilasom, interesuje kako je Đilas. U jednom razgovoru sa Žikom Stojkovićem pitala je za Đilasa pa joj je ovaj ispričao da je Đilasa posetio Ernest Devis, ${ }^{26}$ objašnjavajući joj kako je preko Danila Purića ${ }^{27}$ tražio Đilasovog brata Akima ${ }^{28}$ da bi preko ovoga zakazao sastanak sa Đilasom. To je Mitra prokomentarisala da je to sigurno „odozgo“ namešteno i da se čudi kako Devis i Englezi ne mogu sve to da shvate, kao da su još u devetnaestom veku. Zatim je nastavila da je Đilas istupajući kao patriota $u$ razgovoru sa Devisom govorio da je sve dobro i lepo i da sad Devis na osnovu takvog razgovora nosi pogrešne utiske o Jugoslaviji. U vezi sa tim rekla

${ }^{25}$ Stefanija Štefica Đilas (1921-1993), rođena Barić, druga žena Milovana Đilasa kojom se oženio posle razvoda sa Mitrom Mitrović juna 1952. i 1953. dobio sina Aleksu.

${ }^{26}$ Ernest Davies (1902-1991) britanski novinar i laburistički poslanik, koji se 1954. u Beogradu sastao sa M. Đilasom. http://en.wikipedia.org/wiki/Ernest_Davies_(Enfield_MP); M. Đilas, $n$.d., 296.

${ }^{27}$ Danilo Purić (1923-2005) član KPJ i učesnik NOB, član GK SKS Beograda i CK SKS, glavni urednik i direktor „Politike“, kasnije diplomata. - Ko je ko u Jugoslaviji, Beograd 1970.

${ }^{28}$ Akim Đilas (1927) rođeni brat Milovana Đilasa. Posle rata bio na školovanju u SSSR, a 1948. se upisao na Novinarsku i diplomatsku visoku školu u Beogradu na kojoj je diplomirao 1952. Radio kao novinar u „Politici“ iz koje je izbačen posle III plenuma i potom radio kao korektor u humorističkom listu „Vetrenjača“. - Новинарска и gийломайска висока школа у Беоїраgy 1948-1952, приредио Драгомир Бонџић, Београд 2013, 355-356; Akim Đilas, Beleške jednog korektora, Beograd 2005. 
je: „Ma da, znam ja kako to ide. To je isto kao i samnom. Kad neko hoće samnom da se vidi i da razgovara, ja sve fino, divno pričam o svemu, pa niko posle ne bi rekao da niko od mojih drugova sa kojima sam 20 godina radila neće ni zdravo da mi kaže kako valja“, dodajući uz smeh: „Eh demokratije!" Ona ovako govori pred Žikom jer u njega ima veliko poverenje. Inače ona je vrlo oprezna i nerado govori o političkim pitanjima.

U poslednje vreme se, osim gore navedenih, sastaje i sa Vladom Dedijerom, a često i sa svojim bratom Živanom Mitrovićem ${ }^{29}$ novinarom „Politike“ i njegovom ženom Dankom.

Beograd, 10. XI 1954. g.

4)

Centralnom komitetu Saveza komunista Jugoslavije ${ }^{30}$

Prema zaključku drugova Krste Popivode i Miloša Minića ${ }^{31}$ kao članova Komisije CK koji su imali samnom razgovor 26. novembra 1954. godine treba i pismeno da objasnim svoje držanje pre, za vreme i posle III vanrednog plenuma CK SKJ održanog januara meseca.

Kada je reč o mom držanju pre Plenuma mislim da se taj period može ograničiti na vrlo kratko vreme od Saopštenja CK do Plenuma. To podvlačim zbog toga što sam sve do tog vremena kroz partisko rukovodstvo Srbije, čiji sam aktivni član deset godina, delovala i radila na zadovoljavajući način i sa dosta uspeha u zadacima koje mi je Partija poveravala u posleratnom periodu, prvenstveno prosvetno-kulturnim i agitaciono-propagandnim.

U okviru borbe protiv Kominforma shvatila sam, kao i svi jugoslovenski komunisti, svojim revolucionarnim zadatkom da se borim protiv svega onoga što bi socijalizam, poput sovjetskog, zakočilo u njegovom razvitku. Naša borba, na planu debirokratizacije, koja je zahvatila sve domene našeg ekonomskog, političkog i kulturnog života, snažno me je orijentisala, osobito posle VI kongresa, ka pitanjima socijalističke demokratije i traženju

${ }^{29}$ Živan Mitrović (1905-?) rođeni brat Mitre Mitrović. Završio Pravni fakultet u Beogradu, od 1928. bio novinar, a potom i urednik „Politike“ i dopisnik iz inostranstva. Tokom rata bio u zarobljeništvu u Nemačkoj. Autor nekoliko knjiga. - Ko je ko u Jugoslaviji, Beograd 1970, 684.

${ }^{30}$ Tekst je kucan ćirilicom.

${ }^{31}$ Miloš Minić (1914-2003), završio je Pravni fakultet u Beogradu. Član KPJ od 1936, učesnik NOB od 1941, narodni heroj. Posle rata bio javni tužilac FNRJ, narodni poslanik, ministar, član SIV-a, predsednik Izvršnog veća i Skupštine Srbije, savezni sekretar za inostrane poslove, član CK SKJ, CK SKS, Politbiroa i Izvršnog komiteta CK SKS, itd. Narodni heroji Jugoslavije, Beograd 1975. 
novih oblika u našim uslovima. Možda nisam uvek bila u stanju da odmerim koliko se može i koliko treba u našim uslovima, kada i kako naći najbolje puteve razvijanja oblika socijalističke demokratije. Ali, analizirajući detaljno svoja gledišta po konkretnim pitanjima, koja drugovi iz Izvršnog komiteta CK Srbije preko moga rada sasvim dobro poznaju, ne vidim da bi išta iz tog perioda borbe, makar i pod najoštrijom partijskom ocenom, mogla podvesti pod odstupanje od partijske linije, niti da su moja gledišta izlazila iz okvira naše borbe za razvoj socijalističke demokratije i borbe protiv birokratizma.

U jesen 1953. godine, kada su počeli izlaziti Đilasovi članci u „Borbi“" nalazila sam se kao član jugoslovenske delegacije na zasedanju Ujedinjenih nacija u Njujorku. Vratila sam se polovinom novembra, u vreme izbora, i u povremenim usputnim razgovorima sa drugovima, mada vrlo retko do poslednjih dana decembra, izražavala sam se povoljno o člancima, delimično ih i kritikovala, slično kao i mnogi drugovi. Istina, živela sam, sem $u$ radu, vrlo povučenim životom te u mnogim diskusijama koje su se vodile među drugovima na drugim mestima nisam učestvovala, a na sastancima CK o njima se nisu vodile diskusije. Sa Đilasom se skoro nisam viđala sem kad je dolazio da vidi dete. U redakciju „Nove misli“ ušla sam krajem decembra a rukopise za januarski broj nisam čitala jer sam prisustvovala dotad samo jednom sastanku redakcije.

Sve ovo navodim nešto opširnije da bih objasnila da su me događaji pred Plenum našli potpuno van odnosa koji su se razvijali među drugovima u rukovodstvu CK SKJ - o mnogo čemu sam doznala tek na samom Plenumu - i skoro van diskusija, sem usputnih i poluprivatnih sa nekim članovima o Đilasovim člancima, od kojih su mi se mnogi po tendenciji poklapali sa mojim shvatanjima, jer sam ih sve u celini shvatala, kako sam i na Plenumu govorila, kao pojačani kurs ka razvijanju svih oblika socijalističke demokratije, uopšte i u unutrašnjem partiskom životu, ne videći njihove druge praktično-političke posledice kako ih je ocenio III vanredni Plenum.

Činjenice o mom držanju neposredno pred Plenum i na samom Plenumu su tu pa o njima, sem izvesnih objašnjenja koja sam u više mahova i davala, nema potrebe da opširno pišem. Mene je iznenadila žestina s kojom je veliki deo drugova osuđivao te članke i nisam se pridružila toj borbi računajući da se to još uvek može regulisati na drugi način i sa manje potresa $u$ partiskom životu. Svoje mišljenje o tome nisam skrivala, iznela sam ga i sekretaru CK Srbije. Ni u kakvom širokom krugu, kako mi se to prigovara u partiskim razgovorima, nisam delovala i jedva mogu nabrojati razgovore koje sam imala u tih nekoliko dana i to s drugovima iz mog najužeg partiskog kruga. Đilas je dolazio tih dana nekoliko puta kod mene, takođe i 
Dedijer, i sasvim je prirodno da su nam se razgovori i kretali oko tih događaja i problema.

U spletu svih tih prilika i odnosa našla sam se i na Plenumu. U svojoj diskusiji na Plenumu iznela sam sve vrlo otvoreno što sam tada imala da kažem. Protiv Đilasa nisam istupila oštro jer sam se dotad i sama slagala sa izvesnim stavovima u njegovim člancima, smatrala sam da o tome otvoreno i pošteno treba da kažem nešto i na Plenumu jer su to mnogi drugovi već znali a meni moral nije dozvoljavao da to i ne kažem, a osim toga želela sam da učinim i nešto ka ublažavanju ocene koja će se doneti o Đilasu.

U mome partiskom životu za mene su to bili vrlo teški i burni dani. Moram navesti jedan od krupnih motiva takvog mog držanja na Plenumu svima poznatu činjenicu da sam sa Đilasom provela skoro dvadeset godina zajedničkog života i borbe, još od svojih dvadesetih godina, da imam dete i da je to izvanredno uticalo na moj odnos prema njemu u tim teškim danima koje sam proživljavala na posebno težak način.

Izvlačiti zaključke da je moje istupanje na Plenumu neka organizovana akcija sa Đilasom i Dedijerom smatram da ne stoji ako se analizira moj govor, ako se imaju u vidu moji odnosi sa Đilasom i ako ponovim da ni Đilas ni Dedijer nisu znali da ću ja uopšte govoriti niti je u tom smislu ma ko na mene delovao, a i sama sam se tek na Plenumu odlučila.

Glasala sam za odluku Plenuma, što nije formalna i neznatna činjenica kad se uzmu u obzir sve ove okolnosti koje sam napred navela.

Posle Plenuma našla sam se u situaciji i novim odnosima kakve nisam očekivala kao posledicu mog učešća u diskusiji na Plenumu. U jednom danu, već i na samom Plenumu, doživela sam potpuni javni bojkot koji traje, sada sa nešto manje oštrine, skoro čitavu godinu dana od strane svih mojih drugova s kojima sam više manje radila preko dvadeset godina, jer sam od 1933. godine član Partije. Do mog ponovnog odlaska u SAD, marta meseca, bila sam na jednom razgovoru u Sekretarijatu CK Srbije i na jednom u Izvršnom komitetu gde sam uglavnom iznela sve ovo što sam ovde napisala. Više nisam pozivana ni na kakve partiske i političke sastanke. U aprilu mesecu na Kongresu Saveza komunista Srbije nisam više birana za člana CK Srbije, što sam sve primila i shvatila kao partijske mere zbog mog istupanja na Plenumu. Nastavila sam da vršim svoje poslaničke dužnosti, kao i neke druge sitnije obaveze koje su mi preostale u javnom životu.

Uložila sam ogromne napore da, u tim takvim prilikama i odnosima koji su se stvorili, i u okvirima koji su mi ostali ili pruženi posle Plenuma, u uslovima javnog bojkota - nečeg najtežeg što sam u životu preživela - koji je dejstvovao gde god sam se krenula na poslu, nastavim svoju aktivnost $\mathrm{u}$ društvenom životu, smatrajući svojom obavezom da aktivno radim prema svojim sposobnostima i mogućnostima uprkos svih teškoća koje su se stvo- 
rile u mom životu i radu, uprkos svom potpuno porušenom zdravlju i uprkos sitnih neprilika koje sam sretala i srećem u svakodnevnom životu i radu skoro svaki dan. Mislim da je moj konstruktivni rad za ovu godinu dana, koji se može pratiti, najbolji mogući put koji sam, u ovakvoj svojoj životnoj i partiskoj situaciji, mogla naći kao dugogodišnji komunist i društveni radnik.

Beograd, decembra 1954.

Mitra Mitrović

5)

\section{Pismo drugarice Mitre Mitrović}

Druže uredniče,

u vezi sa izjavama Milovana Đilasa i Vladimira Dedijera „Njujork Tajmsu“ i londonskom „Tajmsu“ i komentarima koje strana štampa donosi povodom toga, osećam potrebu i dužnost da izjavim preko Vašeg lista:

Svako pominjanje moga imena u svim tim komentarima potpuno je proizvoljna konstrukcija. Odbila sam svaki pokušaj stranih novinara da posle tih izjava govore sa mnom i da ma na koji način dam podršku delatnosti Đilasa i Dedijera koju odlučno osuđujem, jer se protivi svim mojim shvatanjima o patriotizmu, socijalizmu i demokratiji, jer ide protiv međunarodnih interesa i ugleda naše zemlje, jer tu delatnost koriste i mogu koristiti u svoje svrhe samo oni krugovi u inostranstvu koji nisu prijateljski raspoloženi prema socijalističkoj Jugoslaviji.

Smatram potrebnim da se javno ogradim od svih tih komentara i od ma kakvog dovođenja moga imena u vezu sa akcijom Đilasa i Dedijera jer ne mogu dopustiti da se moje ime povlači $u$ akciji pokrenutoj $u$ inostranstvu protiv moje zemlje i izgradnje socijalizma u njoj i da inostrana javnost bude krivo obaveštena o ma kakvoj mojoj političkoj podršci Đilasu i Dedijeru.

Smatram potrebnim da se od svega toga ogradim i zbog naše javnosti kako moje držanje na Trećem plenumu CK SKJ ne bi dalo povoda da se moja tadašnja shvatanja, zablude i iluzije, i momenti ličnog karaktera, povežu sa svim tim, utoliko pre što ništa drugo ne želim nego da kao član Saveza komunista $i$ dalje radim $u$ interesu razvitka socijalizma $u$ našoj zemlji.

Beograd, 29. decembar 1954. god.

Mitra Mitrović

/objavljeno u Borbi od 30. decembra 1954. godine/ 